\title{
POLA PENGELOLAAN TANAH ADAT JURANG KOAK DIKAWASAN TAMAN NASIONAL GUNUNG RUNJANI (TNGR) DESA BEBIDAS KECAMATAN WANASABA
}

\author{
Lalu Amrillah'1), Suroso1) \\ 1 Program Studi Pendidikan Geografi Universitas Hamzanwadi \\ Email:59roso@gmail.com
}

\begin{abstract}
ABSTRAK
Penelitian ini dilaksanakan di wilayah Dusun Jurang Koak Desa Bebidas Kecamatan Wanasaba Kabupaten Lombok Timur. Tujuan dari penelitian ini adalah untuk mengetahui bagaimana pola pengelolaan Tanah Adat Jurang Koak Desa Bebidas Kecamatan Wanasaba kabupaten Lombok Timur. Teknik pengumpulan data dalam penelitian ini adalah menggunakan teknik observasi, wawancara, dan dokumentasi. Dalam penelitian ini peneliti mengambil sejumlah informan kunci untuk diwawancarai dengan penarikan sampel didasarkan teknik snowball sampling. Pada penelitian ini, peneliti menggunakan triangulasi sumber. Triangulasi sumber adalah menguji kredibilitas data yang dilakukan dengan cara mengecek data yang telah di peroleh melalui beberapa sumber. Triangulasi sumber akan dilakukan pada pihak pengelola taman nasional gunung rinjani, dibalai taman nasional gunung rinjani dan masyarakat yang mengelola Tanah Adat Jurang Koak. Sedangkan teknik analisis data yang digunakan dalam pengolahan data dengan mengorganisasikan data ke dalam kategori, menjabarkan ke dalam unit-unit melakukan sintesa, memilih mana yang penting dan yang akan di pelajari dan membuat kesimpulan sehingga mudah di pahami oleh diri sendiri maupun orang lain. Analisis data akan di bantu dengan statistik deskriftif. Berdasarkan penelitian yang telah dilakukan di Tanah Adat Jurang Koak di kawasan Taman Nasional Gunung Rinjani Desa Bebidas Kecamatan Wanasaba dapat ditarik kesimpulan, bahwa pola pengelolaan Tanah Adat Jurang Koak di kawasan Taman Nasional Gunung Rinjani Desa Bebidas Kecamatan Wanasaba tidak mempengaruhi lingkungan hidup dan kawasan hutan konservasi. Hal ini dilihat dari pola pengelolaan yang secara kolektif, sarana prasarana yang memadai, dan hasil produksi yang memuaskan. Dan kalau kita lihat dari dampak kepada alam itu sendiri atau hutan itu sendiri tidak terlihat dampak negatif sedikitpun. Karna para petani di Tanah Adat Jurang Koak menanam tanaman agroforestri.
\end{abstract}

Kata kunci: Pola Pengelolaan, Tanah Adat, Taman Nasional Gunung Rinjani 


\section{PENDAHULUAN}

Keberadaan sumber daya hutan di Indonesia meliputi kawasan seluas sekitar 120 juta hektar, hampir 70\% dari luas daratannya, menempati urutan kedua terbesar di dunia setelah brazilia. Dari kondisi ini, menggambarkan peran penting hutan bagi pembangunan ekonomi dan upaya memakmurkan bangsa Indonesia. Menurut Salim (2003), hutan di Indonesia merupakan sumber daya yang sangat bernilai, tidak hanya untuk lingkungan hidup, tetapi juga dari sudut pandang Negara berkembang, untuk pembangunan ekonomi dan politik.

Kebijakan pengelolaan sumber daya hutan alam yang di mulai tahun 1967 yaitu di terbitkannya undangundang pokok kehutanan nomor 5 tahun 1967, telah melahirkan "keajaiban ekonomi" Indonesia pada rentang tahun 1990 an. Menurut Nandika (2005), pada periode tersebut devisa dan pendapatan negara meningkat tajam, infrastruktur berkembang, pusat-pusat pertumbuhan ekonomi di berbagai wilayah terpencil bermunculan, penyerapan tenaga kerja luar biasa, pendapatan perkapita masyarakat meningkat berkali lipat. Pada tahun 1993, nilai ekspor hasil hutan Indonesia mencapai $26,9 \%$ dari seluruh nilai ekspor non-minyak, sedangkan periode tahun 1994-1997 industri hasil hutan telah menghasilkan Sembilan miliar dolar AS pertahun atau rata-rata $7 \%$ dari produk domestik bruto (PDB).

Dari luas keseluruhan 120 juta hektar kawasan hutan di Indonesia, sebesar 1 juta hektar lebih berada di daerah NTB. Berdasarkan undangundang no. 41 tahun 1999 tentang kehutanan, kawasan hutan di NTB di bagi kedalam kelompok hutan konservasi, hutan lindung, dan hutan produksi. Dan dalam penelitian ini akan lebih membahas tentang hutan konservasi di Lombok, yaitu Taman Nasional Gunung Rinjani yang luasnya sekitar 41.330,00 hektar.

Berdasarkan pengamatan peneliti konflik tersebut timbul karena beberapa hal yaitu :Pertama, Menyoroti tanah seluas 150 ha, tempat para petani mengantungkan hidup dengan menggarapnya. Lahan produktif itu sebagai tempat berladang masyarakat Dusun Jurang Koak, Desa Bebidas, Kecamatan Wanasaba, Lombok Timur (Lotim).Namun itu terjadi sebelum tahun 1997. Tahun di mana penetapan kawasan Gunung Rinjani sebagai kawasan suaka marga satwa, yang pada perkembangannya ditetapkan menjadi Taman Nasional Gunung Rinjani (TNGR). Kini, masyarakat adat desa tersebut tersingkirkan.Masyarakat sudah tidak bisa lagi menikmati warisan kekayaan leluhurnya.

Kini, nasib mereka luluh lantak. Masyarakat adat yang mayoritasnya petani terusir dari ruang menyambung hidupnya yang telah jauh hari bertahan hidup di sana. Bahkan sebelum republik ini berdiri. Kedua, meskipun setumpuk peraturan telah di keluarkan melengkapi berlakunya Undang-undang kehutanan yang baru, namun faktanya ketika pemerintah daerah mulai ingin menunjukkan eksistensinya, semua peraturan pusat tak di jalankan.

Penjarahan hutan makin merajalela, ketika tak lagi jelas hutan siapa yang punya. Maka reformasi tak lebih dari sekedar retorika. Bagi sebagian orang, dengan berlindung di 
balik makna kebebasan, reformasi telah memberikan kesempatan mengumbar keserakahan. Dan hutan pun menjadi korban yang nyata dari berkobarnya nafsu ketamakan.Ketiga, penudingan kepada masyarakat lokal sebagai biang kerusakan hutan. Benar memang mereka membuka lahan pertanian di kawasan hutan, tetapi harus pula di pahami tahun 1970, masyarakat jurang koak sudah berada di lahan tersebut. Pada perkembangannya pemerintah melalui Taman Nasional Gunung Rinjani membatasi akses petani untuk menggarap lahan tersebut, karna dianggap lahan tersebut adalah kawasan hutan konservasi Taman Nasional Gunung rinjani. Keempat, pola pengelolaan hutan konservasi Taman Nasional yang tidak sesuai dengan Undang-Undang kehutanan dan peraturan Menteri Kehutanan. Konsep dan pelaksanaan pengelolaan hutan berbasis masyarakat (PHBM) di NTB di kenal dengan nama social forestry yaitu berdasarkan peraturan Menteri Kehutanan Nomor P.01/Menhut-11/2004 tentang pemberdayaan masyarakat setempat didalam dan atau sekitar hutan dalam rangka social forestry. Social forestry merupakan suatu sistem pengelolaan sumber daya hutan pada kawasan hutan Negara dan atau hutan hak, yang memberi kesempatan kepada masyarakat setempat sebagai pelaku dan atau mitra utama dalam rangka meningkatkan kesejahteraan dan mewujudkan kelestarian hutan. Hal penting dari terbitnya peraturan di atas adalah pengakuan Departemen Kehutanan tentang perlunya mewujudkan hutan lestari melalui system pengelolaan hutan berbasis masyarakat (Awang, 2004).
Berdasarkan identifikasi di atas, peneliti menyimpulkan bahwa yang menjadi faktor utama yang menyebabkan konflik antara masyarakat dengan pihak Taman Nasional Gunung Rinjani adalah pola pengelolaan hutan yang tidak sesuai dengan peraturan Menteri Kehutanan. Sehingga peneliti mengambil judul Pola Pengelolaan Tanah Adat Jurang Koak Dikawasan Taman Nasional Gunung Rinjani Desa Bebidas Kecamatan Wanasaba.

\section{METODE PENELITIAN}

Jenis penelitian yang digunakan adalah penelitian kualitatif, lebih tepatnya deskriptif kualitatif yaitu yang akan meneliti objek sosial yang bersifat alamiah tentang pola pengelolaan tanah adat jurang koak di kawasan Taman Nasional Gunung Rinjani (TNGR) di Desa Bebidas Kecamatan Wanasaba. Penelitian ini bersifat kualititatif deskriptif, karena bertujuan untuk mendeskripsikan atau melukiskan realitas sosial tetapi tidak di gunakan untuk membuat kesimpulan yang lebih luas tentang pola pengelolaan tanah adat jurang koak di kawasan Taman Nasional Gunung Rinjani (TNGR) di Desa Bebidas Kecamatan Wanasaba (Sugiyono 2005). Objek alamiah adalah objek yang berkembang apa adanya, tidak dimanipulasi oleh peneliti dan kehadiran peneliti tidak mempengaruhi dinamika pada obyek tersebut (Sugiyono, 2010:8).

Pola pengelolaan tanah adat jurang koak di kawasan Taman Nasional Gunung Rinjani (TNGR) di desa bebidas kecamatan wanasaba merupakan penelitian dengan kualitatif deskriftif dengan menggali informasi dari masyarakat dan intansi 
terkait. Analisis data adalah menorganisasikan data ke dalam kategori, menjabarkan ke dalam unitunit melakukan sintesa, memilih mana yang penting dan yang akan di pelajari dan membuat kesimpulan sehingga mudah di pahami oleh diri sendiri maupun orang lain. Analisis data akan di bantu dengan statistik deskriftif.

Pola adalah bentuk atau model (atau, lebih abstrak, suatu set peraturan) yang bisa dipakai untuk membuat atau untuk menghasilkan suatu atau bagian dari sesuatu, khususnya jika sesuatu yang ditimbulkan cukup mempunyai suatu yang sejenis untuk pola dasar yang dapat ditunjukkan atau terlihat, yang mana sesuatu itu dikatakan memamerkan pola.

Pengelolaan

merupakan

terjemahan dari kata "management", terbawaoleh derasnya arus penambahan kata pungut ke dalam bahasa Indonesia, istilah inggris tersebut lalu diIndonesia menjadi manajemen. Manajemen berasal dari kata to manage yang artinya mengatur, pengeturan dilakukan melalui proses dan diatur berdasarkan urutan dari fungsi-fungsi manajemn. Jadi manajemen itu merupakan suatu proses untuk mewujudkan tujuan yang di inginkan melalui aspek-aspeknya antara lain planning, organising,actuating,dan controling.

Pola pengelolaan hutan di Indonesia secara umum berdasarkan UUD 1945 yaitu pola pengelolaan yang berkeadilan dan berkelanjutan..di manfaatkan dan di pergunakan untuk sebesar-besar kepentingan rakyat.Namun pada praktiknya Negara hanya menjalankan sebagian dari pasal 33 UUD 19456 tentang pemanfaatan dan pengelolaan hutan. Padahal sesungguhnya, semangat pasal 33 UUD mengamanatkan agar penguasaan Negara atas hutan secara bersamasama juga harus mengakomodasi berbagai kelompok kepentingan, tidak hanya kepentingan departemen kehutanan atau sekelompok rimbawan tetapi juga kepentingan petani, peternak, peramu hasil hutan, masyarakat adat dan lainnya.

Hutan juga merupakan salah satu faktor krusial didalam mata rantai permasalahn lingkungan hidup global. Terlepas dari bagaimana implementasi pengelolaan hutan di lapangan, sebenarnya pemerintah Indonesia menyatakan concern terhadap masalah degradasi lingkungan global di antaranya komitmen untuk mengelola hutan secara lestari ( sustainable forest management). Di samping berbasis pada prinsip kelestarian, pengelolaan sumber daya hutan di tuntut untuk memperhatikan juga prinsip multiguna mencakup konservasi tanah dan air, konservasi flora dan fauna, serta fungsi support un tuk program pembangunan lainnya seperti transmigrasi, pertanian dan sarana umum lainnya.

\section{HASIL DAN PEMBAHASAN}

Tanah adat jurang koak adalah kawasan hutan konservasi taman nasional gunung rinjani. Tanah adat jurang koak di jadikan lahan pertanian oleh leluhur masyarakat desa bebidas sebelum Indonesia merdeka. Dibuktikan dengan pengakuan ketua komunitas tanah adat yang mengatakan bahwa tanah adat jurang koak mempunyai dasar hukum yang kuat. Pada zaman hindia belanda ada dua legenda yang mendasari para petani tanah adat jurang koak untuk 
mengelola lahan seluas $150 \mathrm{Ha}$ tersebut.

Pertama yaitu legenda balok imah yang sudah memasuki lahan tersebut ketika masih dalam bentuk hutan belantara. Balok imah dan dan temannya mengubah hutan belantara tersebut menjadi sebuah lahan pertanian yang subur, tetapi ketika itu balojk imah dan temannya belum menetap disana untuk mengelola lahan tersebut. Karna pada zamannya mereka selalu berpindah tempat, atau lebih tepatnya mereka menggunakan pola petani lahan kering.

Kedua yaitu legenda laq ukit yang memasuki lahan tersebut dan menetap disana membangun permukiman untuk bersembunyi dari incaran penjajah hindia belanda, karna lak ukit sangat diinginkan oleh para penjajah karna wajahnya yang sangat cantik. Oleh karna itu laq ukit pergi bersembunyi di lahan tanah adat jurang koak yang sekarang di kelola oleh para masyarakat dusun jurang koak desa bebidas kecamatan wanasaba.

Jadi tanah adat jurang koak adalah tanah warisan leluhur masyarakat desa bebidas yang sampai sekarang terus digarap sebagai lahan pertanian. Walaupun banyak sekali kendala dan masalah yang timbul. Contohnya pada tahun 1997 para pejuang tanah adat jurang koak harus berkonflik dengan pihak Taman Nasional Gunung Rinjani yang mengklai tanah adat jurang koak sebagai kawasan Taman Nasional Gunung Rinjani. Konflik terus berlangsung sampai dibawa ke jalur hukum olehpihak taman nasional gunung rinjani karna para petani tidak mau meninggalkan lahan tanah adat jurang koak yang sudah sejak dulu dikelola oleh leluhur mereka.
Hasil penelitian pada aspek pola pengelolaan ini adalah Mengenai Pola Pengelolaan Tanah Adat Jurang Koak menggunakan pola pengelolaan secara kebersamaan dan menanam tanaman agroforestri. Artinya setiap keputusan yang diambil dalam hal yang berkaitan dengan pengelolaan tanah adat jurang koak harus di musyawarahkan bersama semua anggota komunitas pejuang tanah adat jurang koak, ketika senang semua harus ikut senang, dan konsep pengelolaannya mengatakan bahwa tidak boleh dipindah tangankan atau di jual lahan yg dimiliki di Tanah Adat Jurang Koak.

Kelembagaan untuk mengelola tanah adat jurang koak yaitu komunitas pejuang tanah adat jurang koak dengan jumlah anggota pada awal berdirinya tahun sebanyak 650 orang. Kelompok tani ini dibentuk dengan tujuan untuk mencari jalan keluar yang cepat dan tepat dalam memecahkan permasalahan, kesepakatan bersama dalam mengatasi masalah bersama, serta berbagi pengalaman mengenai masalah pertanian secara umum maupun kehutanan.

Struktur organisasinya termasuk dalam kategori organisasi modern. Tata hubungan antar pengurus dan anggota kurang berfungsi karena kesibukan masing-masing dalam mengurus lahan pertaniannya (sawah). Anggota kelompok tani adalah penduduk sekitar dan di dalam hutan yang masuk secara aktif dengan melakukan pendaftaran.

Untuk sarana dan prasarana sendiri, tanah adat jurang koak sudah banyak yang tersedia baik yang diterima dari bantuan pemerintah ataupun dari swadaya masyarakat dengan melakukan iuran setiap 
anggota pejuang tanah adat. Artinya setiap sarana prasarana yang ada di tanah adat jurang koak tidak terlalu menjadi masalah yang serius dalam mengelola tanah adat jurang koak. Para anggota dan masyarakat mengelola tanah adat jurang koak dengan mandiri. Ketika membutuhkan suatu sarana dan prasarana, baik itu berupa pipa pengairan, aksesbilitas, kran dan sebagainya, masyarakat melakukan iuran dan melakukan gotong royong untuk mengadakan sarana dan prasarana yang di butuhkan. Memang ada beberapa bantuan dari dinas terkait berupa pengadaan bibit, tetapi sebagian besar srana dan prasaran yang ada di tanah adat jurang koak tersedia dengan swadaya dari masyarakat dan anggota komunitas pejuang tanah adat jurang koak.

Berdasarkan hasil wawancara peneliti dengan beberapa informan kunci bahwa tanah adat jurang koak memanfaatkan Lahan Tanah Adat Jurang Koak dengan menanam beberapa tanaman komoditas dengan bawang putih sebagai komoditas unggulan.

pemasaran hasil produksi untuk sementara pedagang atau pengepul langsung membeli di petani karna aksesbilitas untuk mencapai Tanah Adat Jurang Koak tergolong baik, malahan setiap 10 are lahan bisa di masuki mobil pengangkut hasil panen, sehingga itu memudahkan para pedagang dan pengepul.

\section{KESIMPULAN}

Berdasarkan penelitian yang telah dilakukan di Tanah Adat Jurang Koak dikawasan Taman Nasional Gunung Rinjani Desa Bebidas Kecamatan Wanasaba dapat ditarik kesimpulan, bahwa pola pengelolaan Tanah Adat Jurang Koak di kawasan Taman Nasional Gunung Rinjani Desa Bebidas Kecamatan Wanasaba dikelola dengan pola secara kolektif dan nbersifat dinamis, karena setiap tahunnya anggota komunitas Tanah Adat Jurang Koak dikawasan Taman Nasional Gunung Rinjani akan bertambah dan akan memerlukan lahan yang lebih luas lagi, sehingga akan terus dilakukan perluasan lahan. dan kawasan hutan konservasi.

Hal tersebut dilihat dari pola pengelolaan yang secara kolektif, sarana prasarana yang memadai, dan hasil produksi yang memuaskan. Dan kalau kita lihat dari dampak kepada alam itu sendiri atau hutan itu sendiri tidak terlihat dampak negatif sedikitpun. Karna para petani di Tanah Adat Jurang Koak menanam tanaman agroforestri. Namun yang menjadi penyebab konflik yang berkepanjangan antara pihak Pejuang Tanah Adat Jurang Koak dengan pihak Taman Nasional Gunung Rinjani adalah perbedaan pendapat yang dimana pihak Pejuang Tanah Adat menginginkan Tanah Adat Jurang Koak benar-benar sepenuhnya dimiliki dan dikuasai masyarakat dan di sertifikasi. Sedangkan pihak Taman Nasional Gunung Rinjani mengatakan bahwa Tanah Adat Jurang Koak itu adalah kawasan hutan konservasi Taman Nasional Gunung Rinjani milik Negara dan tidak bisa dimiliki atau di sertifikasi oleh perorangan.

\section{DAFTAR PUSTAKA}

Arikunto, Suharsimi. 2006. Prosedur Penelitian Suatu pendekatan Praktek. Jakarta: Rineka Cipta. 
Arikunto, Suharsimi. 2010. Manajemen penelitian. Jakarta : Rineka Cipta.

Aryadi Mahrus. 2012. Hutan rakyat: fenomenologi Adaptasi Budaya masyarakat. Malang. UPT Penerbitan UMM.

Aryadi, mahrus. 2000. Petunjuk kerja teknik pengembangan hutan rakyat. Banjar baru. BRLKT riam kanan dan yayasan bastari.

Awang, San afri; heri Santoso; wahyu tri widayanti; yuli nugroho; kustomo dan sapardiono. 2001. Gurat hutan rakyat di kapur selatan. Yogyakarta. Penerbit debut press.

Badan Pengelolaan Lingkungan Hidup Jakarta. 2011. "Status Lingkungan Hidup Provinsi Daerah Khusus Ibukota Jakarta 2011". http://bplhd.jakarta.go.id

Bebidas. $2015 . \quad$ Laporan Penyelenggaraan Pemerintahan Desa(LPPD) bebidas kecamatan wanasaba 2015 di akses di http://bebidasdesaku.blogspot.c o.id/ tanggal 5 april 2017

Btngr. 2011. Sejarah Taman Nasional Gunung Rinjani diakses di https://www.tnrinjani.net/tenta ngtngr-16-

sejarahgunungrinjani.html tanggal 5 april 2017.

Djajapertjunda, sadikin. 2003. Mengembangkan hutan milik di Jawa. Jawa barat. Penerbit Alqaprint.

Kartodihardjo H. dan H. Jhamtani. 2006. Politik Lingkungan Hidup dan Kekuasaan di Indonesia, Prakarsa untuk Keluar dari Krisis.

Moleong, Lexy J. 2007 Metode penelitian kualitatif. PT. Remaja Rosdakarya, Bandung.
Badan Pengelolaan Lingkungan Hidup Jakarta, 2011. "Status Lingkungan Hidup Provinsi Daerah Khusus Ibukota Jakarta 2011". http://bplhd.jakarta.go.id.

Departemen Kehutanan. 2007a. Instrument Kehutanan Global. Jakarta: Departemen Kehutanan.

Fisher, R.J., 2000. "Decentralization and Devolution In Forest Management: A Conceptual Overview. "Dalam Enters, T, Durst, P.B and Victor (Eds.). Decentralization of Forest Management In Asia and The Pasifik. FAO and RECOFTC Report N. 18 and RAP Publication 2000/1. Bangkok, Thailand.

Nurrohmat, Dodik Ridho. 2010. Strategi pengelolaan hutan. Yogyakarta. Pustaka belajar .

Salim, Emil. 2003. Hutan dan masyarakat Indonesia dalam era perubahan. Dalam carol J.P.C dan ida ayu pradiyo resosudarmo. Kemana harus melangkah? Masyarakat, hutan, dan perumusan kebijakan di Indonesia. Jakarta. Penerbit yayasan obor indonesia

Sugiyono. 2010. Metode penelitian kuantitatif,kualitatif,dan $\quad$ R\&D. Bandung: Alfabeta

Tika, Pabundu. 2005. Metode penelitian geografi. Jakarta : bumi aksara .

Widayati, Wahyu Tri; Slamet Rianto dan Bariatul himmah. 2005. Kajian Potensi Hutan Rakyat dan Analisis Interaksi Masyarakat dengan Sumberdaya Alam di Kabupaten Boyolali. Jurnal Hutan Rakyat. Volume VII No. 2 Tahun 2005. ISSN: 1411-1861. Pustaka Hutan Rakyat, Yogyakarta. 
Zulkifli arif. 2014. Dasar-dasar ilmu lingkungan. Jakarta. Salemba tekni 